\title{
Humanization in the management of hospitalized children and adolescents
}

\author{
Gianluigi Gargantini \\ From 70th Congress of the Italian Society of Pediatrics, Joint National Meeting SIP, SICuPP, SITIP \\ Palermo, Italy. 11-14 June 2014
}

The rights of infants and children in hospital, which are universally accepted from an ideological point of view, result as being only partially applied and in a nonhomogenous way in the different realities[1-3]. Many countries have set standards which would allow the translation of these principles into clinical practice. In 2008 the Italian Pediatric Society (SIP) and the Foundation for Children in Hospital, with the support of Progea \& Joint Commission International, drafted a specific manual in which the requirements to be satisfied are clearly expressed and in which they also started up a voluntary accreditation programme of paediatric departments. The humanization of hospitals is a continually evolving process in relation to the changing needs of children and to the context in general. The current reference model is the Patient and Family Centered Care (PFCC) [4]. Intervention is required at all levels.

Training: this represents the foundation of the process and should examine the numerous aspects such as communication, management of relationships, cultural competence and teamwork.

Organization: activation of alternative assistance models, or models integrated to hospital admission; admission into spaces which are separated from those of adults (it occurs in $72.2 \%$ of subjects between $0-17$ years of age and in 16\% of those between 15 and 17); dedicated paths and guaranteed paediatric treatment in all areas of assistance, including the emergency area; family centered round care which represents the hospital paradigm of the PFCC concept in which the multidisciplinary discussion is carried out within the room, in the presence of the child and the family, integrating their outlook in the decision process; organizational flexibility and in the procedures [5].

Structure: the wards should be designed with the concept of a "paediatric hospital" within a general hospital where

Department of Pediatrics, Lodi, 26900, Italy
Table 1 SIP SURVEY OF 237 PEDIATRIC WARDS - 2010

\begin{tabular}{cl}
\hline ASPECTS OF HOSPITALITY & $\%$ \\
\hline NO SINGLE ROOM & 23 \\
\hline ADOLESCENT HOSPITALIZATION AREA & 26 \\
\hline GAMES ROOM & 91 \\
\hline ADOLESCENT ENTERTAINMENT AREA & 23 \\
\hline SCHOOL & 53 \\
\hline VOLUNTEER ASSOCIATION & 61 \\
\hline AVAILABILITY OF A CULTURAL MEDIATOR & 74 \\
\hline
\end{tabular}

minors are cared for in dedicated areas and with sufficient flexibility to respond to the various needs. The optimal number of single rooms is a subject of debate. For adolescents, separated areas which safeguard privacy and independence are essential. Spaces for support activities and family members' comfort must be provided for (table 1).

Information and education: aimed at actively involving the children and the families in the decisions and in the treatment, but also at understanding one's rights.

It is fundamental to have a strong local leadership that drives the change with group work, alliances with institutions and involving children and families. Validated measures of process and outcome are necessary.

Published: 11 August 2014

References

1. Foster $M$, Whitehead $L$, Maybee $P$, Cullens V: The parents', hospitalized child's and health care providers' perceptions and experiences of family centered care within a pediatric critical care setting. A metasynthesis of qualitative research. J Fam Nurs 2013, 19:431-468.

2. Kelly $M$, Jones $S$, Wilson $V$, Lewis $P$ : How children's rights are constructed in family-centered care: a review of the literature. J Child Health Care 2012, 16:190-205.

3. Migone M, Nicholas F, Lennon R: Are we following the European charter? Children, parents and staff perceptions. Child Care Health Dev 2008, 34:409-417. 
4. Committee on Hospital Care and Institute for Patient and Family Centered Care: Patient-and family-centered care and the pediatrician's role. Pediatrics 2012, 129:394-404.

5. Mittal V, Sigrest T, Ottolini M, Rauch D, Lin H, Kit B, Landrigan C, Flores G: Family-centered rounds on pediatric wards: a PRIS network survey of US and Canadian hospitalists. Pediatrics 2010, 126:37-43.

doi:10.1186/1824-7288-40-S1-A31

Cite this article as: Gargantini: Humanization in the management of hospitalized children and adolescents. Italian Journal of Pediatrics 2014 40(Suppl 1):A31.

Submit your next manuscript to BioMed Central and take full advantage of:

- Convenient online submission

- Thorough peer review

- No space constraints or color figure charges

- Immediate publication on acceptance

- Inclusion in PubMed, CAS, Scopus and Google Scholar

- Research which is freely available for redistribution

Submit your manuscript at www.biomedcentral.com/submit 